\title{
Matching user needs to technology in dementia care: experiences with the Alma Supervisor Educational Program
}

TORHILD HOLTHE', E, IDA WULFF-JACOBSEN², E, F

\author{
${ }^{1}$ Norwegian National Advisory Unit on Ageing and Health, Tönsberg, Norway \\ ${ }^{2}$ Norwegian National Advisory Unit on Ageing and Health/Alma's House, Centre for Professional \\ Development, Nursing Home Agency, Oslo Municipality, Norway
}

A - Study Design, B - Data Collection, C - Statistical Analysis, D - Data Interpretation, E - Manuscript Preparation,

$\mathbf{F}$ - Literature Search, $\mathbf{G}$ - Funds Collection

Summary The number of individuals with dementia in Norway is more than 78,000, and, as in all other European countries, this figure is expected to rise over the coming decades. The Norwegian Health Directorate encourages municipalities to make use of 'welfare technology' in order to contribute to independent living and quality of life in older adults, to increase the quality of community health care, to save time when providing community health services and to reduce costs, e.g. admission to a nursing home. Introducing welfare technology to care recipients requires innovation on the part of the community health care service with regard to increasing the competency of the staff in the operation of the technologies, as well as in establishing an infrastructure for 'digital communication'. Research has shown that access to assistive technology may support individuals with mild cognitive impairments, as well as in an early phase of dementia. However, it is crucial that the technology addresses an identified need, and that the device is tailored to the person's preferences and context. Therefore, it is important to train health professionals to assess the user's needs and preferences and to identify resources and limitations in the particular context. Alma's House in Oslo is a demonstration site and education center for welfare technologies. The education program for the certification of Alma supervisors has become an important strategy in educating occupational therapists (OTs) and nurses on how to assess user needs, identify appropriate technology and implement this into the care recipient's home.

Key words: activities of daily living, Alzheimer disease, self-help devices.

Holthe T, Wulff-Jacobsen I. Matching user needs to technology in dementia care: experiences with the Alma Supervisor Educational Program .Fam Med Prim Care Rev 2016; 18(4): 492-496, doi: 10.5114/fmpcr.2016.63710.

\section{Background}

The aim of this paper is to describe an educational program about how to use modern technology for older adults with dementia and their family caregivers, which has been developed for the staff of community health services. In this context, the assessment of individual's needs is of great importance.

There is great optimism regarding the potential of technology to support older adults with dementia at home. However, in order to match this technology to individual needs, community health staff must be capable of identifying the user's needs and requirements.

In Norway, there is a political will to invest in welfare technologies to support older adults and individuals with dementia. This aims to provide safety, facilitate independent living, relieve caregiver burden and increase the efficiency of the community health services.

The prevalence of dementia is increasing worldwide due to an ageing population* [1] (see Attachment for a definition of dementia). Dementia is the most common reason for permanent stay in a nursing home [2]. An increased burden on caregivers has led to a higher risk of admission to nursing homes [3]. Dementia in close relations is challenging; being the primary family caregiver of a person with dementia is associated with a higher degree of mental, physical, social and economic burden [4-6] compared to family caregivers of individuals with physical diseases [6-8].

In Norway, $60 \%$ of individuals with dementia live at home [9], and they usually become increasingly dependent upon help from family, friends and community health services [8]. Therefore, it is important to investigate the potential of technology to compensate for skills that deteriorate and to contribute to safety and security, as well as reduce the worry and stress of family caregivers. Research has found that assistive technologies (AT) may support everyday living in the early phases of dementia [10-14]. Amongst others, AT that support time orientation, a simple mobile phone and GPS have shown to be useful for individuals in an early stage of dementia [15]. In particular, one study found that access to AT reduced the tension between the person with dementia and the family caregiver, as a result of improved independence in everyday living, and increased feelings of safety

\footnotetext{
*According to the International Classification of Diseases 10 (ICD-10), dementia is defined as follows: Dementia (FOO-FO3) is a syndrome due to disease of the brain, usually of a chronic or progressive nature, in which there is a disturbance of multiple higher cortical functions, including memory, thinking, orientation, comprehension, calculation, learning capacity, language and judgement. Consciousness is not clouded. The impairments of cognitive function are commonly accompanied, and occasionally preceded, by deterioration in emotional control, social behaviour or motivation. This syndrome occurs in Alzheimer disease, in cerebrovascular disease and in other conditions primarily or secondarily affecting the brain (http://apps.who.int/classifications/icd10/browse/2010/ en\#/F00-F09Retrieved August 4, 2016).
} 
[16]. A Swedish study showed that family caregivers of 130 individuals with dementia experienced a moderate burden of care, and there were strong associations between the degree of burden experienced and the quality of the relationship. Caregivers with lower burdens reported significantly better perceived health and higher mean scores of a sense of coherence compared to caregivers with higher burdens [17].

However, in order for technology to be accepted and useful, it has to address a need that is experienced by the user and/or family caregiver [18-20]. Furthermore, the technology must be selected according to the person's needs, habits and preferences [19], and it must be individually tailored [18] in order to be incorporated and accepted as a part of their everyday living arrangements [21].

Nyglrd states that individuals with dementia may already have trouble in using "everyday technology", which refers to devices in the home, such as a TV remote control, a mobile phone or a shaver [22]. Such experiences may very well reduce the motivation for testing new and simpler devices. Thus, introducing new assistive devices to individuals with dementia is crucial, and efforts must be taken in order for this to be successful [18]. A mismatch between a device and the person's cognitive abilities may indicate a poor analysis of user needs. The therapeutic potential of the device must be explored in order to match the functionality and user interface to the person's needs, abilities and capacities [16]. If this not achieved, the chance of the device being rejected increases.

\section{The Human Activity Assistive Technology Model - 'HAAT model'}

The HAAT model proposes a framework for understanding the role of technology within the lives and contexts of individuals with disabilities. Four components are integrated into the model: the human, the activity, the technology and the context, and these interact dynamically due to varied and changing conditions. Technology that may work for a person in one situation may not be effective for another person, or in a different context. It is therefore necessary to identify technology that matches a person's needs and requirements and tailor the technology individually in order to ensure its effective use and benefit [23].

\section{Welfare technology}

In Norway, a governmental initiative is being taken towards integrating assistive technologies, also called 'welfare technologies' (i.e. bringing welfare to the care recipients), into community health services. Older individuals are encouraged to live at home for as long as possible, and welfare technology is to be an integrated part of community services by 2020 [2]. A national program invited 31 municipalities to take part in testing different technologies (electronic pill dispensers, GPS and electronic door-locks, amongst others) and to formulate procedures for running and organizing such technologies as part of their community health services [24]. The aim of bringing technologies into community health services is to support independent living and improve the quality of life of the care recipients, as well as to increase the quality of care, save time and reduce costs [25].

The concept of 'Welfare technology' is defined as:

Technological assistance that contributes to an increase in security, safety, social participation, mobility and physical and cultural activities and which strengthens the individuals' ability to cope independently in everyday living, in spite of diseases or a decreased social, psychological or physical level of functionality. Welfare technologies may support family caregivers and contribute to improvements in accessibility, utilization of resources and quality of services. Welfare technology solutions may prevent the need for community services or transition to institutions (author's translation) [26].

Welfare technology is divided into four groups of technologies: 1 . Safety and security; 2 . Health 'surveillance'; 3. Wellbeing; 4. Coping with everyday life [13, 27].

The issue is: how do we go about providing welfare technology to older adults that may benefit from it?

\section{Alma's House plays an important part in knowledge translation}

The national initiative on including welfare technologies in community health services requires new and innovative ways of providing services. Alma's House is part of the Centre for Professional Development within the Agency for Nursing Home Services in the municipality of Oslo. Oslo is the capital of Norway, with more than 1.5 million citizens and 15 administrative districts. Alma's House and the Centre for Professional Development are responsible for the provision of educational training programs on dementia and geriatrics for community health staff. Since welfare technology is recommended in the governmental plans, a training course aiming at educating supervisors on the use and implementation of welfare technology was developed in collaboration with the National Advisory Board on Ageing and Health.

\section{Table 1. Examples of technologies and purposes Purpose of technology \\ 1. Technology for safety and security: provides safe home en- vironments. Provides social contact and participation in order to prevent loneliness. May contribute to individuals living at home for a longer period of time.} 2. Health surveillance technologies (for assessments and treat-
ments at home).

3. Technologies for wellbeing: to build awareness about own health and prevent ill health.

4. Technologies for coping with everyday living and own health-related problems. Technologies for patients with chronic and/or psychiatric illness and those within rehabilitation programs.

\section{Examples of technologies}

Safety alarms, stove timer, door sensor alarm, bed sensor alarm, GPS (localization technology), fall indicator, camera solutions, electronic door-locks, verbal reminders if an unwanted situation occurs, e.g. leaving the house at night. Video-communication.

Safety monitoring. Advanced medical equipment used for assessments and treatments in the patient's home, e.g. check-ups for COPD patients. Applications for monitoring and selfreporting of health status.

Wearables to monitor conditions of the body: training clock, pulse meter, activity wristband, log sleep patterns, etc. Robot vacuum cleaner, robot lawnmower, smart-home solutions and communication technology for social contact and interaction.

Simple-to-use mobile phones, simple TV remote control, electronic medicine dispensers, digital calendar with activity plan and reminders, digital games such as Wii, Xbox, etc. 


\section{Planning an educational program}

The aim of the Alma Supervisor Educational Program was to increase the knowledge, skills and competencies of occupational therapists (OTs) and nurses working with individuals with dementia, regarding welfare technologies, implementation and follow-up. After being certified, the OT/nurse may invite a client with dementia and their family caregiver to Alma's House to demonstrate and test various technologies in a home-like environment.

Malinowsky et al. (2013) found that health care professionals in a Swedish study requested more information about technology and its use in order to support their clients with dementia. After participating in a one-day course, they said they had learnt "a new way of thinking", i.e. "ways to detect, assess and support the use of technology for individuals with dementia in everyday living" [28].

\section{Content}

The educational program contains both theory and practice, with a 3-hour course once a week over a period of 3 weeks. The pedagogical methods are lectures, group discussions, reflections and hands-on experience with different technological devices. The latter was important for technological skill building. Thereafter, a 2-hour written exam on technology-related case management is required in order to obtain the Alma supervisor certificate.

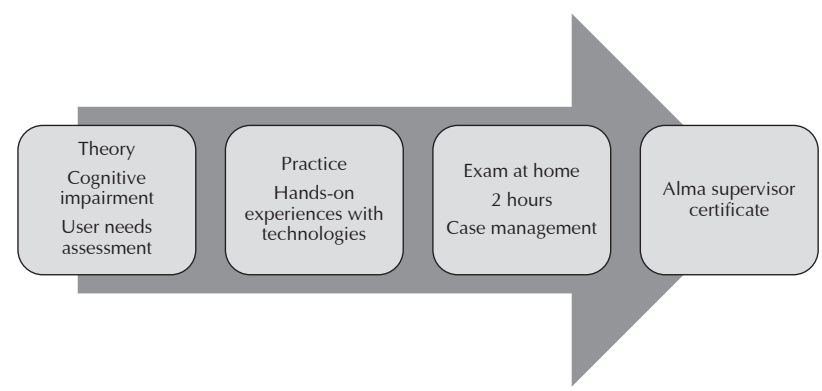

\section{What is included in an assessment of user needs?}

The assessment of user needs should take place in the person with dementia's home. The first home visit should contain a security check, which involves the person with dementia guiding the OT/nurse through the home, discussing potential risks and how to make the environment safer. During this tour through the house, the OT/nurse will observe the person with dementia's ability to explain their environment, observe how they use the stove, the TV remote control or set the temperature on an electrical heater, for example. This helps the OT/nurse get an impression of the person with dementia's level of functionality and what resources can be used as a foundation when evaluating individual needs and selection of potential assistive technologies.

The process of carrying out an assessment of user needs must always be on an individual basis. During the home visit, the following questions may be relevant for inclusion in the conversation:

- Presently, what is a normal day like?

- What activities do you prefer/like the most?

- What activities do you like the least?

- Has anything become difficult or troublesome?

- Do you have any strategies to help you? What are these?

- $\quad$ Do you use a phone/mobile phone/PC, watch TV/ /find preferred channels/read the clock, use the door lock and keys/elevator, etc. independently?
- If not, who is helping you?

- What about rhythm of day and night? Sleep patterns?

- Social contacts: do you spend a lot of time alone, or do you spend time with family/friends? Indoors or outdoors?

- Is there anything you worry about?

- What about your family members? What do they think about the situation?

When a technological device is selected, the implementation procedure is of utmost importance in order to achieve optimal individual tailoring. One cannot anticipate that individuals with the same diagnosis may benefit equally from an assistive device [15].

\section{Results of the Alma Supervisor Educational Program}

The first Alma Supervisor Educational Program was run in 2013. A total of 23 Alma supervisors (occupational therapists and nurses) were certified in 2014, and by August 2016, the number had increased to 53. The supervisors carried out visits to Alma's House with 50 individuals with dementia from nine districts of Oslo in the years 2013-2015, usually together with a family caregiver. The number of visitors with dementia and caregivers for 2016 is 29 (as of September 1).

\section{Discussion}

\section{Assessing dementia and practical consequen- ces of cognitive impairment}

In Norway, the general practitioner (GP) usually assesses the type and degree of dementia. The Mini-Mental-StateExamination (MMSE) [29] and Clock-Drawing-Test [30] are frequently used screening instruments. However, these instruments cannot assess how a person copes with everyday living at home. Therefore, dementia assessment should include an observation examining the level of functionality in everyday tasks in the person's normal context. Observing how a person performs different activities (occupational performance) should contain both an assessment of quality and capacity (quantity) of performing the task, as well as a task analysis and an evaluation of the contextual factors that influence the setting. This is complex, and personal habits, preferences, will and motivation influence the performance [31]. There are some assessment tools available (in Norwegian), and these are increasingly becoming more known to community health care services. In particular, there are the 'Midtnorske kartleggingsverktřy' (Mapping Tool from MidNorway) [32], 'SINTEF evaluation tool regarding needs for welfare technology' [33] and the 'ABC for welfare technology', which was recently launched [27]. These are all useful instruments for community staff and are free to use. A stronger collaboration between the GP and OT/nurses regarding dementia assessment and the best way to support the person with dementia and the primary family caregiver may liberate unused resources that also enable the person with dementia and the family caregiver to take part in decisions regarding ways of getting support from community health services.

\section{How easy or difficult is investigating user ne- eds, preferences, abilities and capacities?}

Individuals with dementia are often older adults. They have established routines and habits through many years of living; they know very well what they prefer and how they want things to be. Identifying user needs in individuals with 
dementia is challenging, since they may not remember what tasks they struggle with during the day. Therefore, Nygård et al. suggested that such assessments should take place in the context that represents the challenge for the person, as this may facilitate conversation about the problematic activity [34]. Observation of occupational performance, such as handling an object, provides a wealth of information about the person with dementia's performance ability, resources and limitations. For example, if the person with dementia complains about difficulties with a mobile phone, they may demonstrate how they use the phone, and the person's performance can be mapped regarding their abilities and capacities in relation to the functional requirements of the task [34]. This observation provides important information, which is essential when selecting and recommending another device for the person. A device that the person can cope with, and that addresses an identified need, seems to be accepted more easily.

When identifying user needs, an analysis of what the problem consists of is necessary. The analysis may contain such questions as: What is the current problem? When does the problem occur? For whom is this a problem, and in what way? Have you thought of a way to solve this problem? This demonstrates the complexity of the assessment of user needs and the follow-up. User participation and collaboration with the family caregiver - and often the community health care staff - is necessary in order to build a 'safety-net' that can ensure that the technology is individually tailored and functions correctly.

\section{Can welfare technology make a difference?}

Research has shown that technology may assist and support individuals with dementia and their caregivers, if it addresses their needs, particularly in the early phases of dementia [35-39]. However, the incorporation of new technology into everyday living is seldom straightforward. Small steps forward and follow-ups in close collaboration with family caregivers and other supporting individuals that agree upon acting as a 'safety-net', are necessary strategies in order for the successful implementation of new technologies. According to Lindqvist et al., the person with dementia must have faith in the device and feel that it makes things easier or improves their capacity or coping in some way, or enables them to reach their goals [15]. A device is accepted more easily if it is suitable for a certain context and is compatible with other technological solutions in the home [19].

\section{Conclusions}

The Alma Supervisor Educational Program was developed as a response to the Norwegian governmental initiative on welfare technology. The successful implementation of welfare technology is critical in order to obtain 'person-fit' technology that will deliver 'a socio-economic gain'. Successfully implementing technology for individuals with dementia means we must always have an individual approach rather than providing the same technology to all community health care receivers. Although knowledge about welfare technology has increased in community health care, there is still a lack of awareness at all levels of community health care about how assistive technologies can support cognitively, how to assess user needs, and how to configure the implementation of these technologies in the care recipients' homes. This means that skill building and a re-organization of tasks and routines must take place in the community health services.

Source of funding: This paper was written with financial support from the Norwegian National Advisory Unit on Ageing and Health (Ageing and Health).

Conflict of interest: The authors declare no conflict of interests.

\section{References}

1. Alzheimer Europe. Dementia in Europe 2014. National care pathways for people living at home. Luxembourg: Alzheimer Europe; 2014.

2. HOD. Morgendagens omsorg. Meld. St 29 (2012-2013). Oslo: Helse-og omsorgsdepartementet; 2013.

3. Bostrom F, Jônsson L, Minton L, et al. Patients with Lewy body dementia use more resources than those with Alzheimer's disease. Int J Geriatr Psychiatry 2007; 22(8): 713-719.

4. Etters L, Goodall D, Harrison BE. Caregiver burden among dementia patient caregivers: a review of the literature. J Am Acad Nurse Pract 2008; 20(8): 423-428.

5. Ulstein I, Bruun Wyller T, Engedal K. The relative stress scale, a useful instrument to identify various aspects of carer burden in dementia? Int J Geriatr Psychiatry 2007; 22(1): 61-67.

6. Måvall L, Thorslund M. Does day care also provide care for the caregiver? Arch Gerontol Geriatr 2007; 45(2): $137-150$.

7. Zeisel J. I'm still here. A new philosophy of Alzheimer's care. New York: Penguin Group; 2009.

8. Black B, Johnston D, Rabins P, et al. Unmet needs of community-residing persons with dementia and their informal caregivers: findings from the maximizing independence at home study. J Am Geriatr Soc 2013; 16(12): 2087-2095.

9. Engedal K, Haugen PK. Demens - Fakta og utfordringer. En lærebok. 5. utgave ed. Tønsberg: Forlaget Aldring og helse; 2009.

10. Astell A. Technology and personhood in dementia care. Quality in Ageing and Older Adults 2006; 7(1): 15-25.

11. Buettner LL, Yu F, Burgener SC. Evidence supporting technology-based interventions for people with early-stage Alzheimer's disease. J Gerontol Nurs 2010; 36(10): 15-19.

12. de Oliviera Assis L, Tirado MG, de Melo Pertence AE, et al. Evaluation of cognitive technologies in geriatric rehabilitation: a case study pilot project. Occup Ther Int 2010; 17(2): 53-63.

13. Frantzen L, ed. Helsedirektoratets anbefalinger på det velferdsteknologiske området. Oslo: Helsedirektoratet 2014.

14. Jensen L, Sørensen LV, Månsson I, et al. Teknologi og demens i Norden. Hvordan bruker personer med demens tekniske hjelpemidler. Fra intervjuundersøkelse i Danmark, Finland, Island, Norge og Sverige. Tønsberg: Forlaget Aldring og helse; 2008.

15. Lindqvist E, Nygard L, Borell L. Significant junctures on the way towards becoming a user of assistive technology in Alzheimer's disease. Scand J Occup Ther 2013; 20(5): 386-396.

16. Gillespie A, Best C, $\mathrm{O}^{\prime}$ Neill B. Cognitive function and assistive technology for cognition: a systematic review. J Int Neuropsychol Soc 2012; 18(1): 1-19.

17. Andrén S, Elmståhl S. The relationship between caregiver burden, caregivers' perceived health and their sense of coherence in caring for elders with dementia. J Clin Nurs 2008; 17(6): 790-799.

18. Holthe T. Velferdsteknologi - også aktuelt for personer med demens! Ergoterapeuten 2011; 54(6): 42-45. 
19. Lindqvist E, Larsson T, Borell L. Experienced usability of assistive technology for cognitive support with respect to user goals. NeuroRehabilitation 2015; 36(1): 135-149.

20. Carswell A, McCullagh P, Augusto J, et al. A review of the role of assistive technology for people with dementia in the hours of darkness. Technol Health Care 2009; 17(4): 281-304.

21. Arntzen C, Holthe T, Jentoft R. Tracing the successful incorporation of assistive technology into everyday life for younger people with dementia and family carers. Dementia (London) 2016; 15(4): 646-662, doi: 10.1177/1471301214532263. Epub 29.04.2014.

22. Rosenberg L, Nygård L, Kottorp A. Everyday Technology Use Questionnaire: Psychometric evaluation of a new assessment of competence in technology use. OTJR: Occupation, Participation and Health 2009; 29(2): 52-62.

23. Cook AM, Miller Polgar J. Framework for assistive technologies. In: Essentials of assistive technologies. USA: Elsevier; 2012.

24. Helsedirektoratet. Nasjonalt Velferdsteknologi Program. 2014 [cited 14.09.16]. Available from URL: http://helsedirektoratet. no/helse-og-omsorgstjenester/omsorgstjenester/velferdsteknologi/nasjonalt-velferdsteknologiprogram-nvp/Sider/default.aspx.

25. Helsedirektoratet. Første gevinstrealiseringsrapport med anbefalinger. Nasjonalt velferdsteknologiprogram. Oslo 2015. [cited 14.09.16]. Available from URL: https://helsedirektoratet.no/Lists/Publikasjoner/Attachments/1139/F\%C3\%B8rste\%20gevinstrealiseringsrapport\%20-\%20Nasjonalt\%20velferdsteknologiprogram.pdf.

26. NOU 11. Innovasjon i omsorg. Helse-og omsorgsdepartementet; 2011.

27. Samveis. Velferdsteknologiens ABC. Oslo 2016.

28. Malinowsky C, Rosenberg L, Nygård L. An approach to facilitate healthcare professionals' readiness to support technology use in everyday life for persons with dementia. Scand J Occup Ther 2014; 21(3): 199-209.

29. Folstein MF, Folstein SE, McHugh PR. „Mini-mental state”. A practical method for grading the cognitive state of patients for the clinician. J Psychiatr Res 1975; 12(3): 189-198.

30. Shulman KI. Clock-drawing: is it the ideal cognitive screening test? Int J Geriatr Psychiatry 2000; 15(6): 548-561.

31. Kielhofner G. A model of human occupation. 3 ed. Baltimore: Lippincott, Williams \& Wilkins; 2002.

32. Velferdsteknologinettverket DM. Kartleggingsverktøy. 2014 [cited 14.09.16]. Available from URL: https://ogbedreskalvibli. files.wordpress.com/2014/07/kartleggingsverktc3b8y-med-veileder.pdf.

33. SINTEF. Verktøy for kartlegging av brukerbehov - velferdsteknologi. 2014 [cited 14.09.16]. Available from URL: http://www. sintef.no/globalassets/project/velferdsteknologi/trygghetspakken/verktoy-for-kartlegging-av-brukerbehov---velferdsteknologi. pdf2014.

34. Nygård L. How can we get access to the experiences of people with dementia? Suggestions and reflections. Scand J Occup Ther 2006; 13(2): 101-112.

35. Cohen-Mansfield J, Creedon M, Malone T, et al. Electronic memory aids for community-dwelling elderly persons: attitudes, preferences and potential utilization. J Appl Gerontol 2005; 24(1): 3-20, doi: 10.1177/0733464804271277.

36. ENABLE. Enabling Technologies for Persons with Dementia. 2004 [cited 14.09.16]; Available from URL: www.enableproject. org.

37. Faucounau V, Riguet M, Orvoen G, et al. Electronic Tracking system and wandering in Alzheimer's disease: a case study. Ann Phys Rehabil Med 2009; 52(7-8): 579-587.

38. Holthe T. Mot - håp - tålmodighet. Yngre personer med demens og betydningen av å få kognitive hjelpemidler til støtte i hverdagen. Tønsberg: Forlaget Aldring og helse; 2015.

39. Jensen L, Månsson I, Holthe T, et al. How assistive technology support cognitive disability, secure active living for persons with dementia and enhance new interfaces between formal and informal care in the area of dementia. 10th European Conference for the Advancement of Assistive Technology 2009.

Tables: 1

Figures: 1

References: 39

Received: 27.09.2016

Revised: 29.09.2016

Accepted: 29.09.2016

Address for correspondence:

Torhild Holthe, MSC

National Advisory Unit on Ageing and Health

PO Box 2136

3103 Toensberg

Norway

Tel: +47 33341950

E-mail: torhild.holthe@aldringoghelse.no 